\title{
BK Polyomavirus in Renal Transplantation
}

\author{
Alice Kennard ${ }^{1}$, Prof David W Johnson ${ }^{1,2,3}$ and Ross Francis ${ }^{1,2,3^{*}}$ \\ ${ }^{1}$ Department of Nephrology, Princess Alexandra Hospital, Brisbane, Australia \\ ${ }^{2}$ School of Medicine, University of Queensland, Brisbane, Australia \\ ${ }^{3}$ Translational Research Institute, Brisbane, Australia
}

"Corresponding author: Dr Ross Francis, Department of Nephrology, Level 2, ARTS Building, Princess Alexandra Hospital, Ipswich Road, Woolloongabba, Brisbane Qld 4102, Australia, Tel: +61 73176 5080; Fax: +61 73176 5480; E-mail: ross.francis@health.qld.gov.au

Rec date: Sep 10, 2014, Acc date: Nov 13, 2014, Pub date: Dec 02, 2014

Copyright: ( 2015 Kennard A, et al. This is an open-access article distributed under the terms of the Creative Commons Attribution License, which permits unrestricted use, distribution, and reproduction in any medium, provided the original author and source are credited.

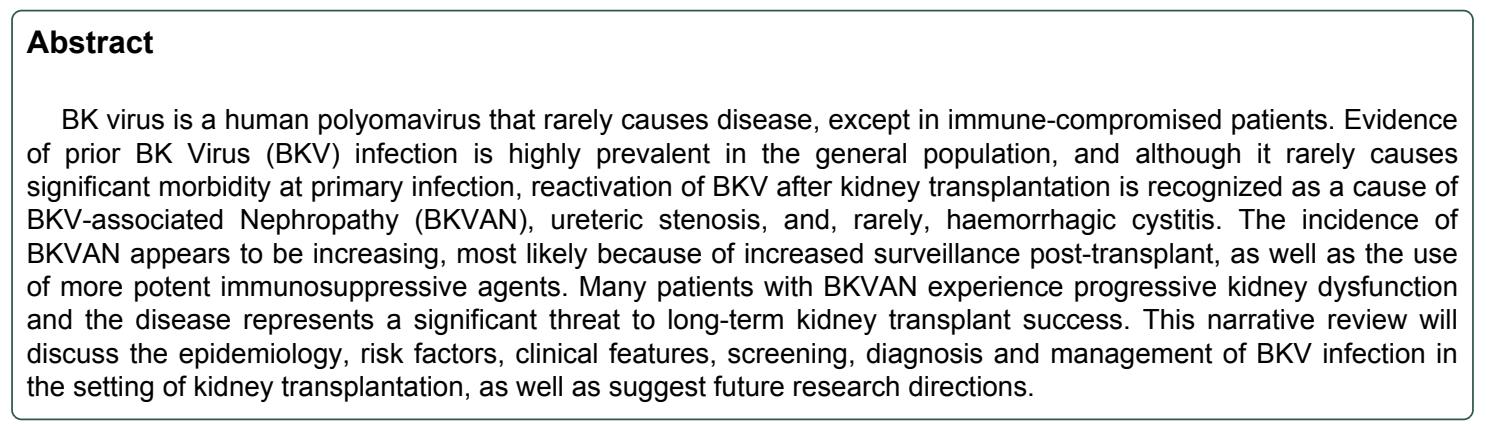

Keywords: $\quad$ BK polyomavirus; Renal transplantation; Immunocompromised, BKVAN

\section{Introduction}

BK Virus (BKV) is a circular, double-stranded DNA virus from the polyomavirus family (Table 1). It was first discovered in the urine of a kidney transplant recipient who had the initials BK2 and is now known to be ubiquitous in humans. Primary infection with BKV appears to be subclinical and typically occurs during childhood. The sero-prevalence is high, measured at $82 \%$ in a population of healthy Swiss adult blood donors and $98 \%$ in healthy 7-9-year-old Finnish children [1-3]. Following primary infection, BKV establishes permanent latency within the uro-epithelium and renal tubular epithelial cells [4]. Asymptomatic urinary BKV shedding was detectable in $8 \%$ of healthy BKV seropositive immune-competent individuals. BKV rarely causes disease unless patients are immunecompromised, such as occurs in the setting of immunosuppression for kidney transplantation. Outside of renal transplantation, BKV is also encountered within bone marrow transplant recipients and in patients with HIV where it also presents as BKV associated nephropathy and haemorrhagic cystitis $[4,5]$. This narrative review will specifically focus on the epidemiology, risk factors, clinical features, screening, diagnosis and management of BKV infection in the setting of kidney transplantation, as well as suggest future research directions.

\begin{tabular}{|l|l|}
\hline Virus & Clinical phenotype \\
\hline BK & BK-virus Associated Nephropathy (BKVAN), ureteric stenosis, haemorrhagic cystitis in immune-compromised patients \\
\hline JC & Progressive multifocal leuko-encephalopathy in immune-compromised patients \\
\hline KI & Respiratory tract infection \\
\hline WU & Respiratory tract infection \\
\hline Merkel cell virus & Neuroendocrine skin cancer (Merkel cell cancer) \\
\hline
\end{tabular}

Table 1: Polyomaviradae that infect humans.

Epidemiology: BK Viruria develops in 30\% of transplant recipients and progresses to viraemia and BK associated nephropathy in $13 \%$ and $7-8 \%$ of transplant recipients, respectively [4,6-8]. This progressively affects graft function and increases the risk of graft loss from $<10 \%$ to approximately $40 \%$ at 3 years follow up $[9,10]$. Even higher rates of graft loss have been described among patients with refectory BK BKVAN or concurrent acute rejection $[11,12]$. Registry data indicate that $\mathrm{BK}$ viraemia and $\mathrm{BKVAN}$ incidence continues to rise with more recent transplant year and the widespread use of potent immunosuppressive drug regimens [13,14]. The substantial decrease in acute rejection rates observed in most centers has not resulted in improved rates of late allograft failure [15], and BKVAN has an important impact on long-term graft function and survival [16-18]. 
Citation: Kennard A, Johnson DW, Francis R (2015) BK Polyomavirus in Renal Transplantation. General Med 3: 1000154. doi:

Page 2 of 10

BKV infection may cause ulceration and stenosis of the transplant ureter usually at the site of ureteric anastomosis. BKV-associated ureteric obstruction has been reported in 3\% of renal transplant patients, occurring between 50 and 300 days post-transplant [19], and has rarely been described following haematopoietic stem cell transplant [20]. Haemorrhagic cystitis due to BKV is a common occurrence (about 10\%) following haematopoietic stem cell transplantation $[21,22]$. The incidence following renal transplantation is unknown.

Risk Factors: The most consistent risk factor identified across studies is the overall degree of immunosuppression [23] (Table 2). Induction therapy with anti-thymocyte globulin (ATG) is consistently associated with sustained viraemia and BKVAN when compared with induction with basiliximab $[13,24,25]$ or no induction7. Use of ATG for either induction or management of acute rejection is associated with a higher incidence of BKVAN on multivariate analysis $(3.53 \%$ versus $1.44 \% ; \mathrm{P}=0.048$ ) [26]. Basiliximab (anti-CD25 $\mathrm{mAb}$ ) has not been shown to influence BK infection rates [13,27]. The influence of the induction agent, alemtuzumab, is at this stage unclear. Some groups report no increase in rates of $\mathrm{BKV}$ in patients following induction therapy with alemtuzumab (anti-CD52 mAb) compared with induction with less potent agents [28]. The recent Oxford 3C trial reported significantly higher rates of BK viraemia or BKVAN at sixmonths after induction with alemtuzumab compared to basiliximab ( $8 \%$ vs. $4 \%$, hazard ratio $1.92(95 \%$ CI $1.06-3.45) \mathrm{p}=0.03)$ [29]. Desensitisation of highly HLA-sensitised patients with IVIG and Rituximab is also associated with a significantly higher incidence of BK Viraemia [30].

\begin{tabular}{|c|c|}
\hline Risk Factor & Reference \\
\hline \multicolumn{2}{|l|}{ Immunosuppressive Regimen } \\
\hline Anti-thymocyte globulin & {$[13,24-26]$} \\
\hline Alemtuzumab & [29] \\
\hline IVIG & [30] \\
\hline Rituximab & [30] \\
\hline Tacrolimus & {$[4,13,24,31-34]$} \\
\hline Mycophenolate & {$[9,24,34]$} \\
\hline Corticosteroid & {$[7,33,39]$} \\
\hline \multicolumn{2}{|l|}{ Other } \\
\hline Pregnane $\mathrm{X}$ receptor polymorphism NR112 & {$[35,95]$} \\
\hline Donor seropositive & {$[41-43]$} \\
\hline Recipient sero-negative & {$[44,96,97]$} \\
\hline CMV risk profile & {$[8,24,45]$} \\
\hline Paediatric recipient & [27] \\
\hline Advanced donor age & {$[8,13,27,34]$} \\
\hline Advanced recipient age & {$[25,32]$} \\
\hline Male recipient & {$[13,34]$} \\
\hline African-American recipient & [27] \\
\hline High BMI & [24] \\
\hline Greater HLA mismatches & {$[7,8,13,27,34]$} \\
\hline Prolonged cold ischaemia & {$[8,13]$} \\
\hline Delayed graft function & {$[6,13]$} \\
\hline Ureteric stent placement & {$[48,49]$} \\
\hline Biopsy proven acute rejection & {$[7,24,27]$} \\
\hline More recent transplant year & {$[13,14]$} \\
\hline Putative protection & \\
\hline
\end{tabular}


Citation: Kennard A, Johnson DW, Francis R (2015) BK Polyomavirus in Renal Transplantation. General Med 3: 1000154. doi:

\begin{tabular}{|l|l|}
\hline Cyclosporin & {$[4,31]$} \\
\hline mTOR inhibitor & {$[13,26,40]$} \\
\hline HLA C7 allele & {$[42]$} \\
\hline
\end{tabular}

Table 2: Factors associated with increased risk of post-transplant BKV replication and nephropathy.

The choice of calcineurin inhibitor has a significant impact on risk of BK viral disease. In vitro studies demonstrate cyclosporin has antiviral properties against herpes simplex virus, vaccinia virus and HIV-1 and can inhibit primary BKV infection peak, reactivation and NCCR gene rearrangements in monkey models [31]. Recognition of BK viraemia and BKVAN as a clinical entity has increased dramatically over the past 20 years, a time in which there has been a large-scale adaptation of tacrolimus/mycophenolate-based immunosuppressive regimens compared to cyclosporin/azathioprine [40]. Whilst increasing vigilance and adoption of BKV screening are likely to have contributed to the rise in recognition of BKV-associated problems post-transplant, this observation raises suspicion that the use of tacrolimus and mycophenolate may substantially increase the risk of $\mathrm{BKV}$ reactivation. In their open-label, prospective single-centre randomised controlled trial of 200 de-novo adult kidney transplant recipients, Brennan and colleagues reported the highest levels of $\mathrm{BK}$ viruria were evident following the combination of tacrolimus and mycophenolate (MPA) and lowest with cyclosporin and MPA but failed to demonstrate a difference in the rates of BK viraemia [32]. The DIRECT trial provides the best evidence to date regarding the differential impact of tacrolimus and cyclosporin on BK replication [33]. In this study, 682 kidney transplant recipients received basiliximab as an induction agent, MPA and steroids and were randomised to either tacrolimus or cyclosporin. BK viraemia was more common in recipients that received tacrolimus compared to cyclosporin ( $16.3 \%$ vs. $10.6 \%$ at six months $(\mathrm{p}=0.048)$ and $12.1 \%$ vs. $4.8 \%$ at twelve months $(\mathrm{p}=0.004))$. This finding has been replicated in a number of subsequent studies [24] and within US OPTN registry data [13]. Higher BKV titres and higher median BK viral loads were observed within the Tacrolimus arm [33]. The Direct study also demonstrated that tacrolimus trough levels of more than $8 \mathrm{ng} / \mathrm{ml}$ are correlated with BKVAN [24,34] (Table 3). Pharmacogenomic studies of the Pregnane $\mathrm{X}$ receptor involved in drug detoxification indicate polymorphisms of the gene NR1I2 predict higher dose exposure of tacrolimus and imposed significantly higher odds of BK viraemia (adjusted odds ratio 2.76 (95\% CI 1.3-7.73); $\mathrm{p}=0.006$ ) [35]. The triple combination of tacrolimus, MPA and steroids has been particularly implicated in the development of BKVAN. It is worth noting that cyclosporin interacts with MPA and decreases mycophenolate exposure via reduced entero-hepatic recirculation [36-38]. Therefore, combining tacrolimus and MPA may increase the likelihood of excessive immunosuppression and increase BKVAN risk. Studies employing therapeutic drug monitoring have demonstrated that both high tacrolimus levels (trough levels more than 10ng/ml) and MPA AUC0-12hr more than $50 \mathrm{hr} \mathrm{mg} / \mathrm{L}$ are particular risk factors for increased immunosuppression and infection with BK virus [24].

\begin{tabular}{|c|c|c|c|c|}
\hline Treatment & Reference & Immunosuppression adjustment strategy & $\begin{array}{l}\text { Study } \\
\text { number }\end{array}$ & Outcome \\
\hline \multirow[t]{2}{*}{$\begin{array}{l}\text { Immunosuppression } \\
\text { discontinuation }\end{array}$} & {$[25,66]$} & Discontinuation of $\mathrm{CNI}$ or MMF or dose reduction in both & [35] & $\begin{array}{l}19 / 35 \text { maintain allograft } \\
\text { function. CNI withdrawal is } \\
\text { associated with superior } \\
\text { allograft survival compared } \\
\text { to dose reduction strategy. }\end{array}$ \\
\hline & [66] & $\begin{array}{l}\text { Discontinuation of antimetabolite, reduction in } \mathrm{CNI} \text { for } \\
\text { sustained viraemia }\end{array}$ & [23] & $\begin{array}{lcr}12 / 23 & \text { cleared } & \text { BKV. } 5 \\
\text { episodes of } & \text { acute } \\
\text { rejection. No } & \text { allograft } \\
\text { losses. } & & \end{array}$ \\
\hline \multirow[t]{4}{*}{$\begin{array}{ll}\text { Dose } & \text { reduction } \\
\text { immunosuppression } & \text { in }\end{array}$} & [7] & Varied; Calcineurin inhibitor dose reduction or conversion & [5] & $\begin{array}{l}4 \text { out of } 5 \text { patients cleared } \\
\text { BKV. } 3 \text { episodes of } \\
\text { rejection. No allograft } \\
\text { losses }\end{array}$ \\
\hline & & Reduction in MMF dose & [22] & $\begin{array}{l}\text { Viremia resolved in } 20 / 22 \\
\text { patients. }\end{array}$ \\
\hline & [68] & Initial reduction in $\mathrm{CNI}$ followed by discontinuation in MMF & [38] & $\begin{array}{l}\text { Viraemia resolved in } 35 / 38 \\
\text { patients, rejection occurred } \\
\text { in } 3 / 35 \text {. No allograft } \\
\text { losses. }\end{array}$ \\
\hline & [69] & Simultaneous dose reduction $\mathrm{CNI}$ and $\mathrm{MMF}$ & [11] & $\begin{array}{l}\text { Viremia resolved in } 8 / 11,3 \\
\text { episodes of rejection. No } \\
\text { allograft loss. }\end{array}$ \\
\hline Cidofovir & [79] & MMF/CNI reduction with/without "adjuvant" cidofovir & [21] & $\begin{array}{l}\text { 6/8 cidofovir patients } \\
\text { cleared BKV. } 2 \text { acute }\end{array}$ \\
\hline
\end{tabular}




\begin{tabular}{|c|c|c|c|c|}
\hline & & & & $\begin{array}{l}\text { rejections in cidofovir } \\
\text { group. No allograft losses } \\
\text { within the cidofovir group. } \\
\text { Allograft loss in } 9 / 13 \\
\text { control patients. }\end{array}$ \\
\hline \multirow[t]{2}{*}{ Leflunomide } & [77] & MMF replaced with leflunomide & [11] & $\begin{array}{l}\text { Viraemia resolved in } 5 / 11 . \\
1 \text { episode of acute } \\
\text { rejection. } 1 \text { allograft loss. }\end{array}$ \\
\hline & [78] & MMF replaced with "low" dose or "high" dose leflunomide & [21] & $\begin{array}{l}\text { Viraemia resolved in } \\
\text { 11/21. } 4 \text { allograft losses. }\end{array}$ \\
\hline \multirow[t]{2}{*}{ Fluoroquinalone } & [84] & Levofloxacin vs placebo & [19] & $\begin{array}{l}\text { No difference in viral load } \\
\text { between groups at } 1 \text { or } 3 \\
\text { months followup. }\end{array}$ \\
\hline & [85] & $\begin{array}{l}\text { Ciprofloxacin and leflunomide progressive therapy and } \\
\text { reduction in immunosuppression in a stepwise fashion }\end{array}$ & [19] & $\begin{array}{l}\text { Significant reduction in BK } \\
\text { viral load in all } 19 \text { patient. } \\
4 \text { episodes of acute } \\
\text { rejection, no allograft loss. }\end{array}$ \\
\hline \multirow[t]{2}{*}{$\begin{array}{l}\text { Human } \\
\text { immunoglobulin }\end{array}$} & [87] & $2 \mathrm{~g} / \mathrm{kg}$ IV over $2-5$ days & [8] & $\begin{array}{l}\text { Histological changes } \\
\text { resolved in 4/8, viraemia } \\
\text { resolved in 4/8, } 1 \text { episode } \\
\text { of allograft loss. }\end{array}$ \\
\hline & [10] & $1.25 \mathrm{~g} / \mathrm{kg}$ as adjuvant to cidofovir & [12] & $\begin{array}{l}\text { No change in graft } \\
\text { function, viraemia or } \\
\text { outcome }\end{array}$ \\
\hline
\end{tabular}

Table 3: Treatment strategies for BKVAN

Corticosteroid dose also appears to influence the risk of BKV replication post-transplant. Hirsch and colleagues demonstrated that treatment initiated for acute rejection, and specifically corticosteroid use, was significantly associated with BKV replication and nephropathy [7]. Cumulative steroid dose within the first 7 days of transplantation and until month, also correlate with higher levels of BK viraemia [39].

BKVAN has been uncommonly observed in patients receiving mTOR-based regimens [26]. Observational studies indicate a lower incidence of BK viraemia among patients managed with everolimus containing regimens compared to cyclosporin-based immunosuppression [40]. The US OPTN Registry analysis of [48], 292 kidney transplants demonstrated a lower incidence of PVAN in patients discharged on mTOR-based regimen (1.74\% vs. $3.67 \%)$ and multivariate analysis showed a reduction in risk of requiring treatment for BK viraemia when compared with no mTOR use (adjusted hazard ratio 0.69 (95\% CI 0.54-0.89) [13].

Transplantation of organs from seropositive donors into seronegative recipients is associated with increased risk of BKVAN [41-43]. High donor anti-BKV IgG titres are inversely proportional to onset of BK viruria and directly proportional to duration of BK viruria [42]. Low titres of anti-BKV IgA and IgG in renal transplant recipients appear to predict viraemia, suggesting that pre-existing antibodies might confer protection against BKV infection [44].

Several studies have reported a strong association between transplantation of CMV seropositive organs into sero-negative recipients and increased risk of BK viremia and BKVAN $[8,24,45]$. It has been suggested that CMV serostatus may act as a surrogate marker of donor/recipient BKV serostatus, as has been shown for CMV and EBV serostatus [24]. On the other hand, as donor negative recipient positive CMV serostatus corresponds with the highest risk of BKV infection, the CMV naïve allograft may be inflamed by exposure to CMV sero-positivity and is thus predisposed to other opportunistic viral infections [8].

Along with CMV serostatus, a number of other risk factors for BK viraemia and $\mathrm{BK}$ nephropathy have been identified and illustrate the complexities of post-transplant immune function. Independent risk factors such pediatric kidney transplant recipient [27] and advanced donor age $[8,27]$ potentially reflect the infective risk associated with immune naivety and immune senescence, respectively. Other risk factors include male recipient, female donor and African-American status [27] and BMI over $30 \mathrm{~kg} / \mathrm{m}^{2}$ [24], although the explanation for these is less clear. Jacobi and colleagues report that enrolment in a prospective clinical trial appears to be protective for BK viraemia, potentially because of the Hawthorne effect, or alternatively, healthy user bias [8].

The degree of HLA mismatch and HLA sensitisation, (as detected by PRA), are associated with BKV reactivation and BKVAN risk $[8,27]$ and may be surrogate markers for immunological risk, and therefore increased immunosuppressive exposure. Interestingly, the incidence of $\mathrm{BK}$ viremia in $\mathrm{ABO}$ incompatible living donation has been reported as lower than in $\mathrm{ABO}$-compatible transplantation [8] but this finding has been refuted in other studies [46,47]. Certain HLA alleles may specifically modulate risk. Bohl and colleagues demonstrated that the HLA C7 allele may be an important determinant of the ability to control BKV infection and its absence increased the risk of developing sustained viruria by at least 3 -fold [42].

Prolonged cold ischaemia [8], delayed graft function [6] and ureteric stent placement $[48,49]$ are associated with increased risk of BK nephropathy. Other recipient risk factors include dialysis vintage and history of haemodialysis usage [8]. An episode of biopsy proven acute rejection is strongly associated with the subsequent development 
of BK viraemia and BKVAN [7,24,27], likely because of intensification of immunosuppression.

Clinical features of BKV reactivation after transplantation: Following kidney transplantation, BKV reactivation may manifest in a variety of ways but is usually asymptomatic and frequently accompanied by a rise in serum creatinine. BK viral infection injures uro-epithelium, manifesting as typically painless transplant ureteric stenosis or as painful haemorrhagic cystitis. While a common occurrence following stem cell transplantation, haemorrhagic cystitis secondary to $\mathrm{BK}$ virus infection must be differentiated from haemorrhagic cystitis secondary to cyclophosphamide toxicity and adenovirus infection in this patient population. BKV has been infrequently implicated in extra renal pathologies such as pneumonia, encephalitis, hepatitis, retinitis, capillary leak syndrome and malignancy [6].

Biopsy proven acute rejection may coincide with BK virus infection and has emerged as a risk factor for BKVAN and vice versa in a number of studies [8,50]. In their prospective study of renal transplant recipients, Drachenberg and colleagues report concurrence of viral cytopathic changes as well as patchy atrophy and tubulointerstitial changes resembling cellular rejection of borderline or Banff Type 1 classification [9]. This unfortunate relationship represents a predicament to clinical management of BK viral infection and emphasises the importance of histological diagnosis.

Immune response to BKV infection: Innate immune responses are implicated in the host response to BKV. Renal transplant recipients with a high BK viral load exhibit elevated urine levels of IL-1 receptor antagonist protein, IL-3, IL-6 and IL-6 receptor compared with BKVnegative patients [51,52]. This suggests cytokines produced by monocytes and T-helper- 2 cells are involved in BKVAN pathogenesis. Anti-BKV CD4+ and CD8+ T cells are implicated in BK clearance and may provide prognostic information. BKV-reactive memory $\mathrm{T}$ cells can be detected in both healthy volunteers and kidney transplant recipients. In a recent study, Chen and colleagues used $\mathrm{MHC}$ tetramers to detect $\mathrm{BKV}$-reactive $\mathrm{T}$ cells in HLA-A 0201 individuals, demonstrating an inverse correlation between the frequency of BKVreactive $\mathrm{CD} 8+\mathrm{T}$ cells and $\mathrm{BK}$ viral loads in blood and urine [53]. The emergence of virus-reactive IgG antibodies is associated with recovery from BKVAN and BKV clearance in renal transplant recipients in some [54] but not all studies [55].

Screening and diagnosis: Low-level BKV reactivation can be detected via the presence of BKV DNA or 'decoy cells' in urine [56]. Increasing BKV replication leads to detectable BKV DNA in the peripheral blood, occurring in $\sim 10 \%$ of kidney transplant recipients [57]. Persistent BK viraemia is associated with increased risk of BKVAN. The degree of viraemia appears to predict risk of BKVAN with plasma load of $\geq 10,000$ predictive of BK nepropathy $[9,58]$.

In the absence of definitive treatment options, the goal of BK viral screening is to facilitate identification of $\mathrm{BKV}$ reactivation at the viruric or viraemic stage with the aim of preventing progression to BKVAN through timely reduction of immunosuppression. Prospective screening studies indicate that BKVAN usually occurs within the first year post-transplantation with a peak in viruria and viraemia detected at around 3 months in 2 European cohort studies $[59,57]$. International guidelines recommend screening for BKV replication at least every 3 months during the first 2 years posttransplant and annually until the fifth post-transplant year. Adoption of this strategy can identify $80-90 \%$ of patients at risk of BKVAN and allow intervention prior to the development of graft dysfunction. More frequent screening intervals have been shown to facilitate earlier diagnosis and potentially better outcomes [57]. There have been no randomised controlled trials of screening and pre-emptive treatment versus treatment following diagnosis of BKVAN.

The optimal screening method for BK virus is not clear. BKV can be detected within urine or blood and screening may adopt either strategy [6]. BK viral shedding in urine is common and may occur in up to $30 \%$ of renal transplant recipients [7]. Urine can be assessed for cytological abnormality or by quantification of urine BK DNA by PCR. Testing for $\mathrm{BK}$ viruria has the advantages of a high negative predictive value to exclude BK nephropathy, a window period of 6-12 weeks before the onset of viruria and nephropathy, reduced cost and less invasive testing modality [6]. Its use is limited however by the low positive predictive value for PVAN, large physiological fluctuation and delayed reduction in urinary shedding making it inappropriate for monitoring response to therapy [6].

Intense monitoring for $\mathrm{BK}$ viruria and viraemia early after transplantation by PCR coupled with prompt reduction in immunosuppression on detection of persistent viraemia has been explored in a study by Brennan and colleagues [32]. The authors report that adoption of this strategy was associated with resolution of BK viraemia and prevented the development of overt BK nephropathy while also avoiding acute rejection and graft loss. Many centres have adopted similar screening protocols based on real-time PCR of plasma, which has a sensitivity approaching $100 \%$, a specificity of $\sim 90 \%$, a positive predictive value of $50 \%$ and negative predictive value of $100 \%$ for the diagnosis of BK viral infection [60]. The window period from detection of viraemia to progression to BKVAN can be as short as 2-6 weeks, prompting many centres to adopt plasma screening every 1-3 months with a $\mathrm{BK}$ viral load of $>4 \log$ copies $/ \mathrm{ml}$ as a trigger to therapeutic intervention $[6,60]$. As previously mentioned, BK seroprevalence is common and in unable to discriminate those patients at risk of developing BKVAN. Viral culture has limited utility outside of a research setting. Its use is limited by slow rate of tissue culture and lack of available cell lines [61].

Renal biopsy remains the gold standard for the diagnosis of BKVAN. It is recommended in patients with BKV $>4 \log$ copies $/ \mathrm{ml}$ with or without an elevation in serum creatinine concentration [60]. The histological lesion of BKVAN is characterised by an inflammatory lymphocytic infiltrate that resembles acute cellular rejection. The presence of intra-nuclear BK inclusion bodies which stain positive for the large $\mathrm{T}$ antigen or for simian virus 40 is pathognomic. Biopsy diagnosis can be missed due to sampling error and the patchy nature of histological changes [60]. The false negative rate is about $30 \%$ based on a single biopsy core but this improves on repeated sampling [62]. A minimum of two cores is recommended, along with correlation of biopsy results with viruria and viraemia $[5,62]$.

The development of haemorrhagic cystitis or radiological findings of ureteric obstruction should prompt an assessment for BK viruria or viraemia through any of the above mentioned techniques. The presence of BK-induced histological changes is the ureter such as inflammation, epithelial sloughing and fibrosis are necessary to demonstrate causality in the resected ureter.

Management of BKVAN: To date there are no antiviral drugs available with specific activity against BKV [31]. There have also been no randomised controlled trials of interventions in BKVAN, such that the evidence underpinning guideline recommendations is limited to 
case series only. Current guidelines recommend timely diagnosis and intervention aimed at improving a patient's BKV-specific immunity status $[6,63,64]$. The key management strategy is reduction in immunosuppression, but there is a lack of consensus on the optimal approach. Management approaches can include reduction or discontinuation of the anti-metabolite (MPA or azathioprine), reduction in calcineurin inhibitor dose, or conversion from tacrolimus to cyclosporin (Table 3). There is just one systematic review to date which has evaluated these approaches [65].

In a single centre retrospective analysis, discontinuation of one of three immunosuppressive agents (usually the calcineurin inhibitor) significantly improved 1-year graft survival when compared to dose reduction of all three immunosuppressive agents $(87.8 \%$ vs. $56.2 \%$; $\mathrm{p}=0.03$ ) [25]. Antimetabolite withdrawal following detection of BK viraemia has likewise been associated with resolution of BK viraemia while avoiding acute rejection or graft loss in a 5-year follow-up study of a single centre randomised controlled trial [66].

Other studies have evaluated dose reduction in mycophenolate or calcineurin inhibitor and demonstrated efficacy at producing viral clearance following detection of $\mathrm{BK}$ viraemia with success rates of 84-96\% [7,5,67-69]. International guidelines recommend targeting tacrolimus trough levels to $<6 \mathrm{ng} / \mathrm{mL}$ and cyclosporin trough levels to $<150 \mathrm{ng} / \mathrm{mL}$ although some studies have reported success at levels lower than this [68]. Episodes of acute rejection may following reduction in immunosuppression and appear to be common (8.6-60\%), although anecdotally respond to management with pulse steroids without major impact on graft outcome [7,12,50,67-69]. Judicious reduction in immunosuppression must be accompanied by close monitoring for acute rejection.

Conversion from tacrolimus to cyclosporin has been hypothesised to enhance BK-specific immunity [70]. A recent study demonstrated successful reduction in viraemia or viral clearance with reconstitution of BKV-specific T-cell responses after switching from tacrolimus to cyclosporin, although the change was also accompanied by introduction of cidofovir [71].

The optimal management strategy for recipients who experience persistent BKVAN or BK viraemia despite reduction in immunosuppressive medication is unclear. The role of the immunosuppressant, leflunomide, has been evaluated in a case series [65,72-74] following success in vitro [75]. Leflunomide is usually administered orally as a replacement agent following discontinuation of mycophenolate with careful monitoring of blood counts and liver function tests [6]. Its use is limited by significant toxicity including hepatitis, haemolysis, thrombotic microangiopathy, bone marrow suppression and fungal pneumonia. Therapeutic drug monitoring using active metabolite A771726 (teriflunomide) has been proposed to monitor effective dose of leflunomide and toxicity. In one case series of 22 patients, maintenance of A771726 levels between 50 to $100 \mu \mathrm{g} / \mathrm{ml}$ was associated with a reduction in blood and urine viral load over time [76]. A number of other studies have likewise reported viral clearance and improvement of stabilisation in graft function with leflunomide therapy whilst also documenting a number of adverse events $[77,78]$. Regrettably the metabolite does not appear to predict toxicity risk [74].

The use of cidofovir has also been investigated in a number of studies. The majority of these studies demonstrate failure to clear viruria or viraemia $[10,26,79]$. In their analysis of the OPTN/UNOS database, Shah and colleagues concluded that cidofovir therapy did not improve graft survival63. A current randomised placebo- controlled dose escalation study is underway to evaluate safety and efficacy of cidofovir in renal transplant patients with BKVAN.

Fluoro-quinolones can block bacterial DNA replication by inhibiting the bacterial enzymes gyrase and topoisomerase IV. The large $\mathrm{T}$ antigen of $\mathrm{BKV}$ is likewise reliant upon helicase function for replication and is similarly inhibited by Fluoroquinolones $[6,80]$. In vitro studies suggest use of quinolone antibiotics inhibits BKV DNA replication [81] and limit viral growth by diminishing the cell release of viral progeny by more than $90 \%[81,82]$. Clinical interest in fluoroquinolones follows an observational study that reported fluoroquinolone use for Pneumocystis prophylaxis was associated with lower rates of BK viraemia compared with no fluoro-quinolone use [83]. A similar finding was reported among patients exposed to fluoroquinolones for other therapeutic indications [83]. A number of small trials have evaluated the role of ciprofloxacin and levofloxacin in BKV infection. In a prospective study of 236 patients the use of prophylactic ciprofloxacin was associated with a lower rate of BKV infection at 3 months but failed to find a difference however at 12 months post transplantation [80]. Mono-therapy with levofloxacin does not significantly improve BK viral load or allograft function when used in addition to overall reduction in immunosuppression [84], suggesting a limited role in established BKVAN6. A regimen utilising ciprofloxacin in combination with leflunomide was associated with a significant decrease in BKV viral load and improved allograft function in a series of 19 kidney transplant recipients [86].

An in vitro study indicated that co-incubation with pooled human immune-globulins inhibited BKV replication in a cell culture model [86]. This observation suggests the presence of neutralising antibodies against $\mathrm{BKV}$ in intravenous immunoglobulin (IVIG) preparations. There is limited clinical experience with the use of IVIG in kidney transplant recipients with $\mathrm{BKV}$ reactivation. In one study of eight patients with documented BKVAN who received $2 \mathrm{~g} / \mathrm{kg}$ of IVIG over 2-5 days, 4 patients achieved viral eradiation, 4 had no evidence of BKVAN on repeat biopsy and 1 graft was lost at mean follow-up of 15 months [87]. The immune-modulatory effect of IVIG has been proposed to be beneficial [6], particularly where there is evidence of synchronous BKVAN and acute cellular rejection [10]. In a study of 12 patients including 10 patients with concomitant BKVAN and acute cellular rejection, IVIG at $1.25 \mathrm{~g} / \mathrm{kg}$ failed to demonstrate a robust improvement in either graft functional stability or resolution of viraemia [10].

In their systematic review of treatment strategies for BK viral infection, Johnston and colleagues report that immunosuppression reduction alone, or in combination with cidofovir results in a deathcensored graft rate loss of $8 / 100$ patients-years, which increases to $13 / 100$ patient years when leflunomide is combined with immunosuppression reduction [65]. More established forms of BKVAN nephropathy appear refractory to reductions in immunosuppression alone and require more complex therapeutic approaches, although there is currently inadequate safety and efficacy data to recommend IVIG. This single systematic review highlights the low number of well-conducted randomised controlled trials to inform clinical decisions and reveals the poor quality evidence hampered by case series data, trial heterogeneity, small sample size, brief follow-up as well as publication bias.

Management of BK-associated haemorrhagic cystitis is likewise limited by a paucity of evidence [88]. Management strategies have included cidofovir, hyperbaric oxygen therapy, growth factor instillation and surgical intervention. There is grade B evidence for the 
use of MESNA [88]. Antiviral therapy does not appear to reverse ureteric stricture and management of ureteric stenosis relies primarily upon radiologic and/or surgical interventions aimed at relieving the obstruction [32].

Re-transplantation in recipients with BKVAN: Re-transplantation after kidney allograft loss due to BKVAN has been successfully performed and has greatest chance of success where clearance of BK viraemia has been achieved by graft nephrectomy and/or reemergence of a BKV-specific immune response, usually facilitated by reduced or discontinued immunosuppression [6,89]. Reported outcomes have been excellent, with graft survival in line with de novo allografts [90]. Nephrectomy alone has not protected against recurrence of BK viral disease [91].

Future research directions: Clinical experience and multiple case series provide clear evidence that reduction in immunosuppression increases viral clearance in kidney transplant recipients with reactivation of BKV. However, the optimal management of recipients with refractory BKVAN is currently unclear. Studies are in progress that with provide further information on the role of leflunomide, fluoro-quinolones, mTOR inhibitors and cidofovir in this setting. It will be important to evaluate the impact of therapies for BKVAN on important patient-level outcomes such as graft survival, and not simply on BK viral load. Additional agents with potential antiviral activity against $\mathrm{BK}$ virus are under investigation, including retinoic acid. In vitro studies of retinoic acid demonstrate that this agent may inhibit transcriptional transactivation of the c-fos promoter by polyoma virus and prevents polyoma virus induced transformation [92]. Another important goal is to develop better tools to stratify BKV reactivation risk among kidney transplant recipients. A potential approach is to monitor the frequency of BKV-reactive $\mathrm{T}$ cells in the peripheral blood and ongoing studies will evaluate the predictive utility of these assays. A study is already underway evaluating the efficacy and safety of in vitro generated BKV-reactive cytotoxic T cells as a therapy for BKVAN [93]. Currently there is no effective strategy to reduce the risk of $\mathrm{BK}$ reactivation post-transplant. Pre-transplant vaccination would be a potential strategy to generate BK immunity in the low number of individuals who are BK sero-negative; although a $\mathrm{BK}$ vaccine is not clinically available currently. Furthermore, there are data indicating that the neutralising effect of anti-BK antibodies is BK serotype specific [94-97]. Therefore, a multivalent BK vaccine would have the potential both to broaden the immune repertoire of $\mathrm{BK}$ seropositive individuals, and boost BK-reactive memory cells, potentially reducing the likelihood of BK reactivation.

\section{Conclusions}

Reactivation of BKV is common after kidney transplantation and represents an increasing threat to long-term graft survival in the modern transplant era. It is likely that BK viraemia is a marker of excessive immunosuppression, and that immune senescence and other donor characteristics interact with recipient and viral factors to manifest the condition. The risk associated with prolonged cold ischaemia, delayed graft function and concomitant or preceding acute rejection suggests a potential role for inflammation as a trigger to viral replication. Choice of induction therapies and anti-rejection regimens clearly contributes to the risk of BKV reactivation. Currently it remains unclear whether any single drug is associated with particularly high risk for $\mathrm{BKV}$, or whether the risk is related to the overall intensity of immunosuppressive therapy. In the absence of specific antiviral strategies, the cornerstone of current management is cautious reduction in immunosuppression and good clinical outcomes are achievable if prompt immunosuppression reduction and aggressive surveillance is adopted. However, established BKVAN appears more refractory to these measures and randomised controlled trials of treatment and prevention strategies are currently needed to guide therapy and improve outcomes in kidney transplant recipients with BKVAN.

\section{References}

1. Egli A, Infanti L, Dumoulin A, Buser A, Samaridis J, et al. (2009) Prevalence of polyomavirus BK and JC infection and replication in 400 healthy blood donors. J Infect Dis 199: 837-846.

2. Gardner SD, Field AM, Coleman DV, Hulme B (1971) New human papovavirus (B.K.) isolated from urine after renal transplantation. Lancet 1: $1253-1257$.

3. Stolt A, Sasnauskas K, Koskela P, Lehtinen M, Dillner J (2003) Seroepidemiology of the human polyomaviruses. J Gen Virol 84: 1499-1504.

4. Hirsch HH, Steiger J (2003) Polyomavirus BK. Lancet Infect Dis 3: 611-623.

5. Bohl DL, Brennan DC (2007) BK virus nephropathy and kidney transplantation. Clin J Am Soc Nephrol 2 Suppl 1: S36-46.

6. Hirsch HH, Randhawa P, AST Infectious Diseases Community of Practice (2013) BK polyomavirus in solid organ transplantation. Am J Transplant 4: 179-188.

7. Hirsch HH, Knowles W, Dickenmann M, Passweg J, Klimkait T, et al. (2002) Prospective study of polyomavirus type BK replication and nephropathy in renal-transplant recipients. N Engl J Med 347: 488-496.

8. Jacobi J, Prignitz A, Büttner M, Korn K, Weidemann A, et al. (2013) BK viremia and polyomavirus nephropathy in 352 kidney transplants; risk factors and potential role of mTOR inhibition. BMC Nephrol 14: 207.

9. Drachenberg CB, Hirsch HH, Papadimitriou JC, Gosert R, Wali RK, et al. (2007) Polyomavirus BK versus JC replication and nephropathy in renal transplant recipients: a prospective evaluation. Transplantation 84: 323-330.

10. Wadei HM, Rule AD, Lewin M, Mahale AS, Khamash HA et al. (2006) Kidney transplant function and histological clearance of virus following diagnosis of polyomavirus-associated nephropathy (PVAN). Am J Transplant 6: 1025-1032.

11. Binet I, Nickeleit V, Hirsch HH, Prince O, Dalquen P, et al. (1999) Polyomavirus disease under new immunosuppressive drugs: a cause of renal graft dysfunction and graft loss. Transplantation 67: 918-922.

12. Trofe J, Gaber LW, Stratta RJ, Shokouh-Amiri MH, Vera SR et al. (2003) Polyomavirus in kidney and kidney-pancreas transplant recipients.Transpl Infect Dis. 5: 21-28.

13. Dharnidharka VR, Cherikh WS, Abbott KC (2009) An OPTN analysis of national registry data on treatment of BK virus allograft nephropathy in the United States. Transplantation 87: 1019-1026.

14. Namba Y, Moriyama T, Kyo M, Imamura R, Shi Y et al. (2005) Prevalence, characteristics, and outcome of BK virus nephropathy in Japanese renal transplant patients: analysis in protocol and episode biopsies. Clin Transplant 19: 97-101.

15. Lamb KE, Lodhi S, Meier-Kriesche HU (2011) Long-term renal allograft survival in the United States: a critical reappraisal. Am J Transplant. 11: 450-462.

16. Meier-Kriesche HU, Schold JD, Srinivas TR, Kaplan B (2004) Lack of improvement in renal allograft survival despite a marked decrease in acute rejection rates over the most recent era. Am J Transplant 4: 378-383.

17. Chang SH, Russ GR, Chadban SJ, Campbell SB, McDonald SP (2007) Trends in kidney transplantation in Australia and New Zealand, 1993-2004. Transplantation 84: 611-618.

18. Tantravahi J, Womer KL, Kaplan B (2007) Why hasn't eliminating acute rejection improved graft survival? Annu Rev Med 58: 369-385. 
19. Pahari A, Rees L (2003) BK virus-associated renal problems--clinical implications. Pediatr Nephrol 18: 743-748.

20. Hwang YY, Sim J, Leung AY, Lie AK, Kwong YL (2013) BK virusassociated bilateral ureteric stenosis after haematopoietic SCT: vira kinetics and successful treatment. Bone Marrow Transplant 48: 745-746.

21. Gilis L, Morisset S1, Billaud G2, Ducastelle-Leprêtre S1, LabussièreWallet H1, et al. (2014) High burden of BK virus-associated hemorrhagic cystitis in patients undergoing allogeneic hematopoietic stem cell transplantation. Bone Marrow Transplant 49: 664-670.

22. Silva Lde P, Patah PA, Saliba RM, Szewczyk NA, Gilman L et al. (2010) Hemorrhagic cystitis after allogeneic hematopoietic stem cell transplants is the complex result of BK virus infection, preparative regimen intensity and donor type. Haematologica. 95: 1183-1190.

23. Wiseman AC (2009) Polyomavirus nephropathy: a current perspective and clinical considerations. Am J Kidney Dis 54: 131-142.

24. Borni-Duval C, Caillard S, Olagne J, Perrin P, Braun-Parvez L, et al. (2013) Risk factors for BK virus infection in the era of therapeutic drug monitoring. Transplantation 95: 1498-1505.

25. Andrew S. Weiss, Jane Gralla, Larry Chan, Patrick Klem, Alexander C. Wiseman (2008) Aggressive immunosuppression minimization reduces graft loss following diagnosis of BK virus-associated nephropathy: a comparison of two reduction strategies. Clin J Am Soc Nephrol 3: 1812-1819.

26. Benavides CA, Mauiyyedi S, Podder H, Knight R, Kahan BD (2007) BK virus-associated nephropathy in sirolimus-treated renal transplant patients: incidence, course, and clinical outcomes. Transplantation 84: 83-88.

27. Schold JD, Rehman S, Kayle LK, Magliocca J, Srinivas TR, et al. (2009) Treatment for BK virus: incidence, risk factors and outcomes for kidney transplant recipients in the United States. Transpl Int 22: 626-634.

28. Theodoropoulos N, Wang E, Penugonda S, Ladner DP, Stosor V, et al. (2013) BK virus replication and nephropathy after alemtuzumab-induced kidney transplantation. Am J Transplant 13: 197-206.

29. Group T. C. S. C (2014) Alemtuzumab-based induction treatment versus basiliximab-based induction treatment in kidney transplantation (the $3 \mathrm{C}$ Study): a randomised trial. The Lancet [Epub ahead of print], 384: 1684-1690.

30. Barbosa D, Kahwaji J, Puliyanda D, Mirocha J, Reinsmoen N et al. (2013) Polyomavirus BK Viremia in Kidney Transplant Recipients After Desensitization With IVIG and Rituximab. Transplantation.[Epub ahead of print].

31. Barraclough KA, Isbel NM, Staatz CE, Johnson DW (2011) BK Virus in Kidney Transplant Recipients: The Influence of Immunosuppression. J Transplant 2011: 750836.

32. Brennan DC, Agha I, Bohl DL, Schnitzler MA, Hardinger KL, et al. (2005) Incidence of BK with tacrolimus versus cyclosporine and impact of preemptive immunosuppression reduction. Am J Transplant 5: 582-594.

33. Hirsch HH, Vincenti F, Friman S, Tuncer M, Citterio F et al. (2013) Polyomavirus BK replication in de novo kidney transplant patients receiving tacrolimus or cyclosporine: a prospective, randomized, multicenter study. Am J Transplant. 13: 136-145.

34. Mengel M, Marwedel M, Radermacher J, Eden G, Schwarz A et al. (2003) Incidence of polyomavirus-nephropathy in renal allografts: influence of modern immunosuppressive drugs. Nephrol Dial Transplant. 18: 1190-1196.

35. Barraclough KA, Isbel NM, Lee KJ, Bergmann TK, Johnson DW, et al. (2012) NR1I2 polymorphisms are related to tacrolimus dose-adjusted exposure and BK viremia in adult kidney transplantation. Transplantation 94: 1025-1032.

36. Miyakoshi S, Yuji K, Kami M, Kusumi E, Kishi Y, et al. (2004) Successful engraftment after reduced-intensity umbilical cord blood transplantation for adult patients with advanced hematological diseases. Clin Cancer Res 10: 3586-3592.

37. Grinyo JM, Ekberg H, Mamelok RD, Oppenheimer F, Sánchez-Plumed J et al. (2009) The pharmacokinetics of mycophenolate mofetil in renal transplant recipients receiving standard-dose or low-dose cyclosporine, low-dose tacrolimus or low-dose sirolimus: the Symphony pharmacokinetic substudy. Nephrol Dial Transplant. 24: 2269-2276.

38. Gregoor PJ, de Sévaux RG, Hené RJ, Hesse CJ, Hilbrands LB, et al. (1999) Effect of cyclosporine on mycophenolic acid trough levels in kidney transplant recipients. Transplantation 68: 1603-1606.

39. Basse G, Mengelle C, Kamar N, Guitard J, Ribes D et al. (2007) Prospective evaluation of BK virus DNAemia in renal transplant patients and their transplant outcome. Transplant Proc. 39: 84-87.

40. Moscarelli L, Caroti L, Antognoli G, Zanazzi M, Di Maria L et al. (2013) Everolimus leads to a lower risk of BKV viremia than mycophenolic acid in de novo renal transplantation patients: a single-center experience. Clin Transplant. 27: 546-554.

41. Shah KV (2000) Human polyomavirus BKV and renal disease. Nephrol Dial Transplant 15: 754-755.

42. Bohl DL, Storch GA, Ryschkewitsch C, Gaudreault-Keener M, Schnitzler MA et al. (2005) Donor origin of BK virus in renal transplantation and role of HLA C7 in susceptibility to sustained BK viremia. Am J Transplant. 5: 2213-2221.

43. Andrews CA, Shah KV, Daniel RW, Hirsch MS, Rubin RH (1988) A serological investigation of BK virus and JC virus infections in recipients of renal allografts. J Infect Dis 158: 176-181.

44. Randhawa P, Bohl D, Brennan D, Ruppert K, Ramaswami B et al. (2008) Longitudinal analysis of levels of immunoglobulins against $\mathrm{BK}$ virus capsid proteins in kidney transplant recipients. Clin Vaccine Immunol. 15: $1564-1567$

45. Toyoda M, Puliyanda DP, Amet N, Baden L, Cam V, et al. (2005) Coinfection of polyomavirus-BK and cytomegalovirus in renal transplant recipients. Transplantation 80: 198-205.

46. Habicht A, Broker V, Blume C, Lorenzen J, Schiffer M et al. (2011) Increase of infectious complications in ABO-incompatible kidney transplant recipients--a single centre experience. Nephrol Dial Transplant. 26: 4124-4131.

47. Sharif A, Alachkar N, Bagnasco S, Geetha D, Gupta G et al. (2012) Incidence and outcomes of $\mathrm{BK}$ virus allograft nephropathy among $\mathrm{ABO}$ and HLA-incompatible kidney transplant recipients. Clin J Am Soc Nephrol. 7: 1320-1327.

48. Siparsky NF, Kushnir LF, Gallichio MH, Conti DJ (2011) Ureteral stents: a risk factor for polyomavirus BK viremia in kidney transplant recipients undergoing protocol screening. Transplant Proc 43: 2641-2644.

49. Kayler L, Zendejas I, Schain D, Magliocca J (2013) Ureteral stent placement and BK viremia in kidney transplant recipients. Transpl Infect Dis 15: 202-207.

50. Randhawa PS, Finkelstein S, Scantlebury V, Shapiro R, Vivas C, et al. (1999) Human polyoma virus-associated interstitial nephritis in the allograft kidney. Transplantation 67: 103-109.

51. Sadeghi M, Daniel V, Schnitzler P, Lahdou I, Naujokat C, et al. (2009) Urinary proinflammatory cytokine response in renal transplant recipients with polyomavirus BK viruria. Transplantation 88: 1109-1116.

52. Kuypers DR (2012) Management of polyomavirus-associated nephropathy in renal transplant recipients. Nat Rev Nephrol 8: 390-402.

53. Chen Y, Trofe J, Gordon J, Du Pasquier RA, Roy-Chaudhury P et al. (2006) Interplay of cellular and humoral immune responses against BK virus in kidney transplant recipients with polyomavirus nephropathy. J Virol. 80: 3495-3505.

54. Hariharan S, Cohen EP, Vasudev B, Orentas R, Viscidi RP, et al. (2005) $\mathrm{BK}$ virus-specific antibodies and BKV DNA in renal transplant recipients with BKV nephritis. Am J Transplant 5: 2719-2724.

55. Bohl DL, Brennan DC, Ryschkewitsch C, Gaudreault-Keener M, Major EO, et al. (2008) BK virus antibody titers and intensity of infections after renal transplantation. J Clin Virol 43: 184-189.

56. Drachenberg RC, Drachenberg CB, Papadimitriou JC, Ramos E, Fink JC et al. (2001) Morphological spectrum of polyoma virus disease in renal allografts: diagnostic accuracy of urine cytology. Am J Transplant. 1: 373-381. 
57. Alméras C, Vetromile F, Garrigue V, Szwarc I, Foulongne V et al. (2011) Monthly screening for BK viremia is an effective strategy to prevent BK virus nephropathy in renal transplant recipients.. Transpl Infect Dis. 13: 101-108.

58. Hirsch HH, Mohaupt M, Klimkait T (2001) Prospective monitoring of BK virus load after discontinuing sirolimus treatment in a renal transplant patient with BK virus nephropathy.. J Infect Dis. 184: 1494-1495.

59. Koukoulaki M, Grispou E, Pistolas D, Balaska K, Apostolou T et al. (2009) Prospective monitoring of BK virus replication in renal transplant recipients. Transpl Infect Dis. 11: 1-10.

60. Sawinski D, Goral S (2014) BK virus infection: an update on diagnosis and treatment. Nephrol Dial Transplant .

61. Arthur RR, Shah KV (1989) Occurrence and significance of papovaviruses BK and JC in the urine. Prog Med Virol 36: 42-61.

62. Drachenberg CB, Papadimitriou JC, Hirsch HH, Wali R, Crowder C, et al. (2004) Histological patterns of polyomavirus nephropathy: correlation with graft outcome and viral load. Am J Transplant 4: 2082-2092.

63. Acott P, Babel N (2012) BK virus replication following kidney transplant: does the choice of immunosuppressive regimen influence outcomes? Ann Transplant 17: 86-99.

64. Kidney Disease: Improving Global Outcomes (KDIGO) Transplant Work Group (2009) Kidney Disease: Improving Global Outcomes (KDIGO) Transplant Work Group. 3:S1-155.

65. Johnston O, Jaswal D, Gill JS, Doucette S, Fergusson DA, et al. (2010) Treatment of polyomavirus infection in kidney transplant recipients: a systematic review. Transplantation 89: 1057-1070.

66. Hardinger KL, Koch MJ, Bohl DJ, Storch GA, Brennan DC (2010) BKvirus and the impact of pre-emptive immunosuppression reduction: 5year results. Am J Transplant 10: 407-415.

67. Bennett WM, Meyer L, Ridenour J, Batiuk TD (2010) Surveillance and modification of immunosuppression minimizes BK virus nephropathy. Am J Nephrol 32: 10-12.

68. Schaub S, Hirsch HH, Dickenmann M, Steiger J, Mihatsch MJ et al. (2010) Reducing immunosuppression preserves allograft function in presumptive and definitive polyomavirus-associated nephropathy. Am J Transplant. 10: 2615-2623.

69. Alméras C, Foulongne V, Garrigue V, Szwarc I, Vetromile F, et al. (2008) Does reduction in immunosuppression in viremic patients prevent BK virus nephropathy in de novo renal transplant recipients? A prospective study. Transplantation 85: 1099-1104.

70. Acott PD, O'Regan PA, Lee SH, Crocker JF (2008) In vitro effect of cyclosporin A on primary and chronic BK polyoma virus infection in Vero E6 cells. Transpl Infect Dis 10: 385-390.

71. Babel N, Schachtner T, Mueller K, Sattler A, Thiel A et al. (2010) Modifiction of immunosuppression can enhance the reconstitution of $\mathrm{BKV}$-secific immunity preventing graft failure due to $\mathrm{BKV}$-associated nphropathy in renal transplant patients. Transplantation 90.

72. Williams JW, Javaid B, Kadambi PV, Gillen D, Harland R, et al. (2005) Leflunomide for polyomavirus type BK nephropathy. N Engl J Med 352: 1157-1158.

73. Josephson MA, Gillen D, Javaid B, Kadambi P, Meehan S, et al. (2006) Treatment of renal allograft polyoma BK virus infection with leflunomide. Transplantation 81: 704-710.

74. Krisl JC, Taber DJ, Pilch N, Chavin K, Bratton C, et al. (2012) Leflunomide efficacy and pharmacodynamics for the treatment of BK viral infection. Clin J Am Soc Nephrol 7: 1003-1009.

75. Liacini A, Seamone ME, Muruve DA, Tibbles LA (2010) Anti-BK virus mechanisms of sirolimus and leflunomide alone and in combination: toward a new therapy for BK virus infection. Transplantation 90: 1450-1457.

76. Josephson MA, Gillen D, Javaid B, Kadambi P, Meehan S, et al. (2006) Treatment of renal allograft polyoma BK virus infection with leflunomide. Transplantation 81: 704-710.
77. Faguer S, Hirsch HH, Kamar N, Guilbeau-Frugier C, Ribes D (2007) Leflunomide treatment for polyomavirus BK-associated nephropathy after kidney transplantation. Transpl Int. 20: 962-969.

78. Leca N, Muczynski KA, Jefferson JA, de Boer IH, Kowalewska J et al. (2008) Higher levels of leflunomide are associated with hemolysis and are not superior to lower levels for BK virus clearance in renal transplant patients. Clin J Am Soc Nephrol. 3: 829-835.

79. Kuypers DR, Vandooren AK, Lerut E, Evenepoel P, Claes K et al. (2005) Adjuvant low-dose cidofovir therapy for BK polyomavirus interstitial nephritis in renal transplant recipients. Am J Transplant. 5: 1997-2004.

80. Wojciechowski D, Chanda R, Chandran S, Lee B, Webber A, et al. (2012) Ciprofloxacin prophylaxis in kidney transplant recipients reduces $\mathrm{BK}$ virus infection at 3 months but not at 1 year. Transplantation 94: 1117-1123.

81. Ferrazzi E, Peracchi M, Biasolo MA, Faggionato O, Stefanelli S, et al (1988) Antiviral activity of gyrase inhibitors norfloxacin, coumermycin A1 and nalidixic acid. Biochem Pharmacol 37: 1885-1886.

82. Sharma BN, Li R, Bernhoff E, Gutteberg TJ, Rinaldo CH (2011) Fluoroquinolones inhibit human polyomavirus BK (BKV) replication in primary human kidney cells. Antiviral Res 92: 115-123.

83. Gabardi S, Waikar SS, Martin S, Roberts K, Chen J et al. (2010) Evaluation of fluoroquinolones for the prevention of BK viremia after renal transplantation. Clin J Am Soc Nephrol. 5: 1298-1304.

84. Lee BT, Gabardi S, Grafals M, Hofmann RM, Akalin E (2014) Efficacy of levofloxacin in the treatment of BK viremia: a multicenter, doubleblinded, randomized, placebo-controlled trial.Clin J Am Soc Nephrol. 9: 583-589.

85. Zaman RA, Ettenger RB, Cheam H, Malekzadeh MH, Tsai EW (2014) A novel treatment regimen for BK viremia. Transplantation 97: 1166-1171.

86. Randhawa PS, Schonder K, Shapiro R, Farasati N, Huang Y (2010) Polyomavirus BK neutralizing activity in human immunoglobulin preparations. Transplantation 89: 1462-1465.

87. Sener A, House AA, Jevnikar AM, Boudville N, McAlister VC et al. (2006) Intravenous immunoglobulin as a treatment for BK virus associated nephropathy: one-year follow-up of renal allograft recipients. Transplantation. 81: 117-120.

88. Harkensee C, Vasdev N, Gennery AR, Willetts IE, Taylor C (2008) Prevention and management of BK-virus associated haemorrhagic cystitis in children following haematopoietic stem cell transplantation â€ " a systematic review and evidence-based guidance for clinical management. Br J Haematol. 142: 717-731.

89. Ginevri F, Pastorino N, de Santis R, Fontana I, Sementa A (2003) Retransplantation after kidney graft loss due to polyoma BK virus nephropathy: successful outcome without original allograft nephrectomy. Am J Kidney Dis. 42: 821-825.

90. Dharnidharka VR, Cherikh WS, Neff R, Cheng Y, Abbott KC (2010) Retransplantation after BK virus nephropathy in prior kidney transplant: an OPTN database analysis. Am J Transplant. 10: 1312-1315.

91. Hirsch HH, Ramos E (2006) Retransplantation after polyomavirusassociated nephropathy: just do it? Am J Transplant 6: 7-9.

92. Talmage DA, Listerud M (1994) Retinoic acid suppresses polyoma virus transformation by inhibiting transcription of the c-fos proto-oncogene. Oncogene 9: 3557-3563.

93. Papadopoulou A, Gerdemann U1, Katari UL1, Tzannou I1, Liu H1, et al. (2014) Activity of broad-spectrum T cells as treatment for AdV, EBV CMV, BKV, and HHV6 infections after HSCT. Sci Transl Med 6: 242ra83.

94. Pastrana DV, Brennan DC, Cuburu N, Storch GA, Viscidi RP, et al. (2012) Neutralization serotyping of BK polyomavirus infection in kidney transplant recipients. PLoS Pathog 8: e1002650.

95. Barraclough KA, Isbel NM, Lee KJ, Bergmann TK, Johnson DW (2012) NR112 polymorphisms are related to tacrolimus dose-adjusted exposure and BK viremia in adult kidney transplantation. Transplantation. 94: 1025-1032. 
Citation: Kennard A, Johnson DW, Francis R (2015) BK Polyomavirus in Renal Transplantation. General Med 3: 1000154. doi: 10.4172/2327-5146.1000154

Page 10 of 10

96. Ginevri F, Azzi A, Hirsch HH, Basso S, Fontana I (2007) Prospective monitoring of polyomavirus $\mathrm{BK}$ replication and impact of pre-emptive intervention in pediatric kidney recipients. Am J Transplant. 7: 2727-2735.
97. Smith JM, McDonald RA, Finn LS, Healey PJ, Davis CL, et al. (2004) Polyomavirus nephropathy in pediatric kidney transplant recipients. Am J Transplant 4: 2109-2117. 